\title{
Efficacy of Vocational Training as an Integral Part of Entrepreneurship Education as a Transition Programme for Persons with Intellectual Disability in Oyo State
}

\author{
Akinyosoye Michael Olufemi ${ }^{1}$, Jiboye Temitope Favour ${ }^{1, *}$, Olabisi Adewale Olaosebikan ${ }^{2}$ \\ ${ }^{1}$ Institute for Entrepreneurship and Development Studies, Obafemi Awolowo University, Ile-Ife Osun State, Nigeria \\ ${ }^{2}$ Department of Education for Learners with Intellectual Disability, School of Special Education, \\ Federal College of Education (Special) Oyo, Oyo State, Nigeria
}

Copyright $\bigcirc 2017$ by authors, all rights reserved. Authors agree that this article remains permanently open access under the terms of the Creative Commons Attribution License 4.0 International License

\begin{abstract}
Entrepreneurship education no doubt has been accepted as a vital tool in the education of persons with intellectual disabilities as it forms the major objective of their education. It is a system through which pupils with intellectual disabilities could be well rehabilitated appropriately in the area of academic, social, vocation, personal and psychologically. This paper attempts to review the place of entrepreneurship education in the education of persons with intellectual disabilities and also examine to what extent the policy provision for entrepreneurship education has been achieved in the schools for persons with intellectual disabilities with suggestions and recommendations that will better enhance the full implementation of entrepreneurship education in these special schools for optimum success and self-sustenance.
\end{abstract}

Keywords Entrepreneurship Education, Intellectual Disability, Rehabilitation

\section{Introduction}

The primary needs of man are food, shelter and clothing. If education does not make any child procure any of these three then it means all other ideas of education have become meaningless and irrelevant. No one on this planet earth can deny the significance of the economic viability of all the inhabitants in the community, as such education must make persons worthy and contribute their quota no matter how little to the development of his/her society. Civic efficiency is attained through economic independence therefore education must prepare individuals to take up some profession or vocation in his/her nearest future.

Education must train individuals to lead a responsible life, that is, the knowledge the child has acquired in the school must become an instrument in earning a decent income later on in life.

The entrepreneurship education in the most efficient manner affords persons with plan for their career and how they can be self-sustained after leaving the school environment. The entrepreneurship education builds the self-esteem of persons with intellectual disability, and helps them to develop their ability to work independently.

The term entrepreneurship education is a comprehensive one. It is the education that entails a lot of practical or manual work. This concept centres on the idea of ability to work with hands rather than mind with a curriculum of certain manual activities like leather work, wood work, poultry and animal husbandry.

It is an Organized Educational Programme which directly related to preparation of individual for paid or unpaid employment, or for additional preparation for a career. The goal of entrepreneurship education programme is to prepare the students to enter the world of work and to develop the basic academic skills, good work habits, meaningful work value, skills, aptitudes, occupational opportunities, the ability to plan and to make career decisions and securing employment. The basic component of education are specific job training information, personal and social adjustment skills, career information and modified content in subject areas.

Apart from general education, entrepreneurship education indicates acquisition of knowledge and practical skills in different sectors of economic and social life. It prepares the individual to select a particular vocation or 
occupation. It gives practical orientation to education which becomes meaningful and brings utility to the education. It prepares the individual to understand the social reality and to realize his/her potentials within the framework of economic development. Providing education and preparing the children with intellectual disability for various self -employments, an occupation has always been an important task in the total educational system. It prepares the individual to lead a better life and to attain better economic and civic amenities.

It is very much evident that education will enable the child to get economic independence. The economic stability should improve the quality of life of the child with intellectual disability. In today's competitive world it goes without saying that strive hard to prove his capability, to grab the opportunities in the society. When it is difficult for a person with all the organs and senses intact to achieve financial stability, it is even more difficult and challenging for persons with intellectual disability. Considering all the inadequacies that persons with intellectual disability have, unless the system of education increases the level of confidence in them, hence they need vocational skills through entrepreneurship education in order to meet their future challenges.

\section{Statement of the Problem}

Many pupils with intellectual disability are found in schools specially designed to cater for their unique needs, but it has been discovered that the kind of education given to these children is just like that of persons without any disability (to be academically sound). This study is to find out the efficacy of the entrepreneurship education that is being given to these children with intellectual disability and also the availability of necessary infrastructures that will facilitate the teaching of the subject.

More employment opportunities after good education and proper training in particular skills are very essential for persons with intellectual disability, so that they can go forward and become successful economically and self-sufficient. Against this background, it will be appropriate to evaluate the present condition of the school meant to teach these children with intellectual disability so as to evaluate and estimate whether the needed facilities are available in the schools and if not to what extent could the condition be improved on. It also throws more light on the various vocational skills and their relevance, adequacy of technical knowledge of teachers or their short comings and also gives suggestions for improvement.

The other significance of this study would be the linkage of the practical skills provided through a vocation with that of the future occupation of the future of the children with intellectual disability. This study is focused on persons with intellectual disability who are in special primary schools in selected schools in Ibadan Metropolis.

\section{Objectives of the Study}

The following are the objectives of the study:

1. Identify the entrepreneurship educational needs of persons with intellectual disability at the primary school level

2. Identify the courses offered in these special schools and their efficacy

3. Study the existing facilities in these schools in relation to the infrastructure and financial support

\section{Literature Review}

\section{Literature Review}

Gallagher (2002) [1] describes intellectual disability as one of the most powerful and stigmatizing labels. Zhang and Stecker (2001)[2] mention that intellectually disabled students possess an internal barrier, namely "learned helplessness", which makes disabled students believe that they are unable to be involved in their own vocational planning. The American Association on Mental Deficiency for intellectual disability defines intellectual disability as ...a substantial limitation in present functioning. It is characterized by significantly sub-average intellectual functioning, existing concurrently with related limitations in two or more of the following applicable adaptable skills areas communication, self-care, home living, social skills, community use, self-direction, health and safety functional academics, leisure and work (In Landsberg 2005: 381) [3].

This has an effect on their cognitive growth and leads to the community perceiving them as non-responsive and disinterested in life around them (Taanila A, Rantakallio P, Koiranen, Von Wendt L, Jarvelin M. R, 2005)[4]. When managers set a goal of developing and implementing a vocational training and transition planning programme to meet the needs of stakeholders, certain planning steps in development of a programme should be followed (Vlachos 2008)[5].

People with disabilities and their families need to be empowered and take care of their needs in every sphere of their lives (Mpofu et al. 2011) [6]. This implies that people with disabilities and their families have a key role which will require participation to greater extent in various economic processes of their communities. Myezwa and M'kumbuzvi (2003) [7] proposed that participation should exist at series of levels ranging from information giving to initiating action true empowerment. For effective economic empowerment people with disabilities need to take part in empowering activities of their communities such as entrepreneurship. Entrepreneurship is increasingly gaining recognition in both developing and developed countries (Muzari 2011) [8]. Participation by people with disabilities in this 21 st century activity will not only improve the quality of life for people with disabilities but 
make the Sustainable Development goal of poverty reduction attainable by most developing countries.

Development of an Entrepreneur Training Programme for Intellectually Disabled Students Research in the United States has identified a number of programme practices which are associated with the successful vocational training of intellectually disabled students (McDonnell J.J, J-lardman M.L, McDonnell A.P Kiefer- O'Donnell R (1995) [9]. These practices include person-centered transition planning and transition assessment, communityreferenced curriculum and instruction, an individualized Entrepreneur Programme (1 VP) job placement prior to leaving school and the importance of family involvement Sitlington P. L, Clark G. M, Kolstoe O. P (2000) [10]. Unfortunately the field of vocational education and training in Southern Africa has been badly neglected and, hence, the Entrepreneurship training programme in the United States was adapted and used as a framework for developing a suitable programme.

Schumpeter recognising the very high levels of unemployment and poverty across the globe argued that the myopic focus in large projects and organisations created a large gap between the 'haves and have not' (David 2004)[11]. According to David (2004), an entrepreneur is a person who is willing and able to convert a new idea or invention into a successful innovation simultaneously creating new products and business Article 13 of the Disability Rights Charter of South Africa states that disabled people shall he entitled, encouraged and assisted to live independently in their communities and to develop the skills necessary to enable them to live in broader society and they shall be provided with adequate and appropriate support systems to do so (Disability Rights Charter of South Africa). However, very few people, with or without disabilities are totally independent in life, as most people conduct their affairs with mutual reliance on other people (Sitlington et al.2000)[12]

The South African Qualifications Authority (SAQA 2001) maintains that any programme must be planned and developed on the basis of research. Sparg L. Winberg C, Pointer R. (1999)[13] framework was used for developing the vocational training programme. The South African dilemma is that research has not been done in this field previously and that we have to investigate successful programmes that have been implemented in other countries.

Each successful learning experience is a stepping stone to more success and the school is pivotal in creating the conditions for success at school (Engelbrecht P, Green L, Naicker S, Engelbrecht L (2004)[14]. To prepare students for life after school, the goals are interdependence, independence and ultimately independent living (Sitlington et al. 2000)[15]. The importance of entrepreneurship in development of nations was also documented by Smith (2009)[16] in his book Wealth of Nations whereby he was underscoring the significance of invention and innovation as catalysts and vehicle for economic development and requisite tools to poverty eradication. Entrepreneurial success in general seems to be closely related to the motives, skills and attitudes of the entrepreneur (Reijonen and Komppula 2007) [17]. In today's world, small businesses and particularly new ones are seen more than ever as a vehicle for entrepreneurship, contributing not just to employment and social and political stability, but also to innovative and competitive power, (Wennekers and Thurik 1999) [18]. The positive and statically robust link between entrepreneurship and economic growth has been verified across a wide spectrum of units of observation, spanning the establishment, the industry, the region and the country. Confronted with rising concerns about unemployment, job creation, economic growth and international competitiveness in global markets, policy makers have responded to this new evidence with a new mandate to promote the creation of new businesses under the guise of entrepreneurship. Moreover, there is ample evidence that economic activity has shifted away from large firms to small firms during the current millennium and beyond.

Self-employment for people with disabilities is significant from a number of different policy perspectives inter alia, promoting entrepreneurship among disadvantaged groups, narrowing the gap in employment rates between people with disabilities from the rest of the population and preventing social exclusion (Muzari 2011) [19]. Many of the barriers to self-employment are faced by people with disabilities and those without disabilities people alike but for people with disabilities they may be more acute or more difficult to overcome, including disability unfriendly entrepreneurship legal and policy frameworks, access to start-up capital, interaction with the benefit system, and finding out about and accessing appropriate training and advice (Wennekers and Thurik 2007) [20]. The idea that human capital and financial capital are key input factors for the start-up success and growth of firms makes entrepreneurial inaccessible for people with disabilities (Mpofu \& Shumba, 2013) [21] Disability is both the reason for and the consequences of poverty (Mpofu et al. 2011)[22]. Persons with disabilities often lack adequate schooling and have limited access to gainful employment and therefore cannot come up with significant capital to start an entrepreneurial activity. In micro and small enterprises, a single person, usually the owner-manager must have both technical and managerial skills (Bruder J, and Neuberger D) [23]. These skills are rare in people with disabilities as their history shows that they have been denied access to formal education and training (Inge et al. 2008)[24], that would make them capable to engage in entrepreneurial activities. Entrepreneurship as it relates to people with disabilities is fraught with problems Differences in access to credit may be due to discrimination and financial exclusion against them. Most nascent entrepreneurs with disabilities lack 
experience, do not have a history of prior success, and are unable to provide collateral for loans.

Disability was long considered an individual problem that was treated from a charitable viewpoint. The Decade of Disabled Persons (1983-92) proclaimed by the UN and World Programme of Action triggered a change from the care approach to a human rights approach by including the equal rights of persons with disabilities to participate in social processes including developmental issues.

An Individualized Vocational Programme (IVP) was subsequently developed according to the students' individual needs and, together with the input of the team members (parents, class teacher, occupational therapist), they were given an opportunity to have a say in their own education and future. This is in line with the features for a training model as advocated by Jones (2010)[25]. The following concept are briefly discussed.

\section{Job Placement and Training}

The purpose of job/task placements in the school is to provide the students with an opportunity to explore a number of occupations, to gain work experience in the safe surroundings of the school and to learn specific vocational skills. By rotating some of the jobs/tasks after a six-month period the students have the opportunity to be exposed to a number of different lobs/tasks in a one-year cycle. Typically, a skill is considered learned when the student performs the task correctly for three of four consecutive trials without any assistance from the teacher (Inge K. J, Dymond S, Wehman P, Sutphin C, Johnson C. Faina M (2008)[26].

\section{Family Involvement}

Families play a key role as job developers and advocates in marketing their children's skills and abilities. Parents and families should look within their own networks neighbours, colleagues and extended family members-to seek opportunities for their children (Parent brief: Person centered planning: A tool for transition 2004). The ultimate goal of vocational training and transition planning is to attain independence and interdependent living.

\section{Methodology}

Two types of data were used for this study namely, primary and secondary data. Primary data were randomly obtained through the use of structured questionnaire from teachers and students from secondary schools in Oyo State, Nigeria. The respondents are students with intellectual disabilities found in the rehabilitation Centre and other schools for persons with intellectual disabilities where Entrepreneurship training is being taught. Four schools were evaluated to know how the concept of
Entrepreneurship education is handled. Secondary data were obtained from Journals, Periodicals, Internet sources and text books. Data collected were analysed using descriptive method of analysis.

The schools that were sampled are:

a Rehabilitation Center Moniya, Oyo State, Nigeria

b Cheshire School for the Handicapped Ijokodo Oyo State, Nigeria

c L/A primary School Okeho, Oyo State, Nigeria

d Baptist Central Primary School Igboho, Oyo State, Nigeria

\section{Data Presentation and Analysis}

This section deals with the presentation and analysis of data collected for the study.

1. Ascertain the need for entrepreneurship education for persons with intellectual disability at the primary school level

2. Identify the courses offered in these special schools and their efficacy after leaving the school

3. Study the existing facilities in these schools in relation to the infrastructure and financial support from the government

\section{Research Question 1}

Do persons with intellectual disability need entrepreneurship education

Table 1. Showing whether the persons with intellectual disability need entrepreneurship education

\begin{tabular}{|c|c|c|c|c|c|}
\hline SA & A & UD & SD & D & Total \\
\hline 50 & 30 & 4 & 4 & 12 & $100 \%$ \\
\hline & $\mathrm{SA}+\mathrm{A}$ & & & $\mathrm{SD}+\mathrm{D}$ & \\
\hline & $50+30=80$ & 4 & & $4+12=16$ & $100 \%$ \\
\hline
\end{tabular}

The table above represents responses to research question 1 which was captured by question $1-10$ on the questionnaire. It was discovered that $80 \%$ of the respondent believe that persons with intellectual disabilities need entrepreneurship education, $4 \%$ of the respondents were indifferent while $16 \%$ of the respondents showed negative responses to the research question.

\section{Research Question 2}

Will job opportunities be available to persons with intellectual disabilities after they are exposed to entrepreneurship education?

Table II. Showing whether job opportunities be available to persons with intellectual disabilities after they are exposed to entrepreneurship education

\begin{tabular}{|c|c|c|c|c|c|}
\hline SA & A & UD & SD & D & Total \\
\hline 49.5 & 32.25 & 4 & 3.75 & 10.5 & $100 \%$ \\
\hline & SA $+\mathrm{A}$ & & & SD $+\mathrm{D}$ & \\
\hline & $49.5+30.25=81.75$ & 4 & & $3.25+10.5=14.25$ & $100 \%$ \\
\hline
\end{tabular}


Data collected with respect to research question 2 which comprise of questions 11-20 which were descriptively analyzed and the findings shows that $81.75 \%$ of the respondents were favourably disposed to job being given to persons with intellectual disabilities after their exposure and $14.25 \%$ were not favourably disposed to it.

\section{Research Question 3}

Are the existing facilities in these schools in relation to the infrastructure and financial support from the government adequate?

Table III. Showing if the existing facilities in these schools in relation to the infrastructure and financial support from the government are adequate

\begin{tabular}{|c|c|c|c|c|c|}
\hline SAD & AD & UD & SIA & ID & Total \\
\hline 10.25 & 8.75 & 15 & 42.5 & 23.5 & $100 \%$ \\
\hline & SA $+\mathrm{A}$ & & & SD $+\mathrm{D}$ & \\
\hline & $10.25+8.75=19$ & 15 & & $42.5+23.5=66$ & $100 \%$ \\
\hline
\end{tabular}

Data collected with respect to research question 3 which comprise of questions 21-30 which were descriptively analyzed and the findings shows that $19 \%$ of the respondents agreed that the facilities and financial supports are adequate. $15 \%$ were undecided while the rest $66 \%$ disagree that the facilities and financial supports are adequate

\section{Discussion of Findings}

From the study conducted, $80 \%$ of the respondent believes that vocational education is relevant and should be administered to person with intellectual disabilities which will give them the opportunity to contribute their quota towards the development of the society as well as enable them to be self-actualized. $16 \%$ of the respondents do not believe that persons with intellectual disabilities will benefit from vocational education, while $4 \%$ were undecided.

So also, based on data presented on table ii, $81.75 \%$ of the respondents strongly agreed that person with intellectual disabilities are fit for job and can also provide job after they have being given vocational education. $4 \%$ were indifferent to the fact that these people can provide job for themselves and can also employ others, while $14.25 \%$ were of the opinion that the process of entrepreneurship education cannot lead persons with intellectual disabilities to leaving independent life.

To finalize the findings, research question 3 shows that $19 \%$ of the respondents agreed that the facilities and financial supports are adequate. $15 \%$ were undecided while the rest $66 \%$ disagreed that the facilities and financial supports are adequate, thereby making it a little difficult for them to really equip the children with what is needed for them

\section{Summary and Conclusion}

The research attempted at investigating the efficacy of vocational training as an integral part of entrepreneurship education as a transitional programme for persons with intellectual disability in Oyo state. This study looked at the impact of entrepreneurship education with emphasis on person with intellectual disabilities, how the programme will benefit them and what will be the influence on them.

Based on the finding, it was discovered that people in the school (the teachers and the students) so much believe that persons with intellectual disabilities are capable of learning one vocation or the other and also that they can be self-reliant based on their experience.

In the light of the foregoing the following recommendations are made.

1. Government should invest more in the entrepreneurship education for persons with intellectual disabilities.

2. Massive awareness programme should be created among the populace about the usefulness of entrepreneurship education among persons with intellectual disabilities

3. Schools for persons with intellectual disabilities should be well equipped so as to ensure appropriateness and relevance of education.

4. Loans should be made available to persons with intellectual so as to enable them put into practice whatever they have learnt

5. Job opportunities should be given to persons with intellectual disabilities so as to enable them space in the public service. 


\section{Appendix I}

\section{Questionnaire for Teachers of Persons with Intellectual Disability \\ INSTITUTE FOR ENTREPRENEURSHIP AND DEVELOPMENT STUDIES \\ OBAFEMI AWOLOWO UNIVERSITY ILE - IFE, OSUN STATE NIGERIA}

This is a research work meant to obtain information on Efficacy of Vocational Training as an integral part of Entrepreneurship Education as a Transition Programme for Persons with Intellectual Disability in Oyo State. Please kindly note that the exercise is solely for academic purpose. We therefore solicit for your maximum cooperation as the information obtained will be treated with utmost confidentiality. Thank you

\section{SECTION A: BIODATA}
(1) Gender of the Respondents
(a) Male
(b)Female
(2) Religion
(a) Islam
(b) Christian
(c) Traditional
(3) Age as at last Birthday
(4) Educational Qualification
(a) Primary
(a) Married
(b) Secondary
(c) Tertiary
(d) No formal education
(5) Marital Status
(b) Single
(c)Divorced
(d)Widow
(e) Separated

Please tick the appropriate options that matches your answer below

\begin{tabular}{|c|c|c|c|c|c|c|}
\hline $\mathrm{S} / \mathrm{N}$ & & SA & A & UD & $\mathrm{D}$ & SD \\
\hline 1 & Cognition is essential in teaching Entrepreneurship Education & & & & & \\
\hline 2 & Persons with Intellectual Disability have enough cognition for Entrepreneurship & & & & & \\
\hline 3 & Vocational training will empower persons with Intellectual Disability & & & & & \\
\hline 4 & Entrepreneurship education will make persons with Intellectual Disability independent & & & & & \\
\hline 5 & $\begin{array}{l}\text { Government alone should be saddled with providing entrepreneurship education for persons with } \\
\text { Intellectual Disability }\end{array}$ & & & & & \\
\hline 6 & $\begin{array}{l}\text { There are enough manpower to teach persons with Intellectual Disability entrepreneurship } \\
\text { education }\end{array}$ & & & & & \\
\hline 7 & Self-employment for persons with Intellectual Disability is possible after training & & & & & \\
\hline 8 & $\begin{array}{l}\text { Vocational training and Entrepreneurship education promote integration of persons with Intellectual } \\
\text { Disability into the society }\end{array}$ & & & & & \\
\hline 9 & $\begin{array}{l}\text { There are enough facilities available in providing entrepreneurship education for persons with } \\
\text { Intellectual Disability }\end{array}$ & & & & & \\
\hline 10 & $\begin{array}{l}\text { Parent should be involved in providing entrepreneurship education for persons with Intellectual } \\
\text { Disability }\end{array}$ & & & & & \\
\hline 11 & Teachers teaching entrepreneurship education to persons with Intellectual Disability are qualified & & & & & \\
\hline 12 & National policy on education promote entrepreneurship education for persons with ID & & & & & \\
\hline 13 & Any education given to persons with Intellectual Disability is mere charity & & & & & \\
\hline 14 & Family involvement in entrepreneurship education is vital & & & & & \\
\hline 15 & On completion of training, persons with Intellectual Disability are employed by the government & & & & & \\
\hline
\end{tabular}

Note

SA- Strongly agree

Agree

UD- Undecided

D- Disagree

SD- Strongly Disagree.

$202-210$.

\section{REFERENCES}

[1] Gallagher E (2002) Adult clients with mild intellectual disability: Rethinking our assumptions. ANZJF)1 23(4):
[2] Zhang D, Stecker P.M (2001). Student involvement in transition planning: Are we there yet? Education and Training in Mental Retardation and Developmental Disabilities, 36(3): 293-303.

[3] Landsberg F. (2005). Addressing Barriers to Learning: A 
South African Perspective. Pretoria: Van Schaik.

[4] Taanila A, Rantakallio P, Koiranen M, Von Wendt L, Jarvelin MR (2005). How do persons with intellectual disability manage in the open labour markets? A follow-up of the Northern Finland 1966 birth cohort Journal of Intellectual Disability Research, 49(3): 2 18-227.

[5] Vlachos C.J (2008). Developing and Managing a Vocational Training and Transition Planning Programme for Intellectually Disabled Learners. Doctorate in Education Management Thesis. Unpublished. University of South Africa: Pretoria.

[6] Mpofu J, Gasva D, Gwembire J, Mubika D (2011). Introduction to Special Needs Education. Harare: Zimbabwe Open University.

[7] Myezwa H, M'kumbuzvi VRP 2003. Participation in community based rehabilitation programmers in Zimbabwe: Where are we? Asia Pacific Disability Rehabilitation Journal, 18(1): 56-633.

[8] Muzari WM (2011). Small Enterprise Development. Harare: Jongwe Printing and Publishing Company.

[9] McDonnell J.J, Hardman ML, McDonnell A,P, KieferO'Donnell R (1995). An Introduction to Persons with Severe Disabilities. Boston: Allyn Bacon.

[10] Sitlington P.L, Clark G.M, Kolstoe O.P (2000). Transition Education and Services/for Adolescents with Disabilities. Boston: Allyn and Bacon.

[11] David R. (2004). Schumpeters Market Enterprise and Evolution. Massachusetts: Edward Eldger Publishing Inc.

[12] Op. cit. Sitlington et al.2000

[13] Sparg L, Winberg C, Pointer R (1999). Learning About Educational Management. Cape Town: Juta.

[14] Engelbrecht P, Green L. Naicker S, Engelbrecht L. (2004). Inclusive Education in Action in South Africa. Pretoria: Van
Schaik.

[15] Op. cit. Sitlington

[16] Brett R. Smith, Charles H. Matthews and Mark T. Schenkel (2009). Differences in Entrepreneurial Opportunities: The Role of Tacitness and Codification in Opportunity Identification. Journal of Small Business Management. Vol. 47, Issue $1 \mathrm{Pg}$ : 38-57,

[17] Reijonen and Komppula (2007) Perception of success and its effect on small firm performance Journal of Small Business and Enterprise Development Vol 14, Issue 4

[18] Wennekers S, Thurik R (1999) Linking entrepreneurship and economic growth. Small Business Economics, 13: 27-55.

[19] Op. cit. Muzari 2011

[20] Op. cit Wennekers S, Thurik R 1999

[21] Jabulani Mpofu and Almon Shumba(2013) Disabilities and Entrepreneurship in Makonde Rural Community in Zimbabwe. Stud Tribes Tribals, 11(2): 135-144.

[22] Op. cit. Mpofu et al. 2011

[23] Bruder J, and Neuberger D. (2011) Financial constraints of ethnic entrepreneurship: evidence from Germany. International Journal of Entrepreneurial Behavior \& Research Vol. 17, Issue 3

[24] Inge K.J, Dymond S, Wehrnan P, Sutphin C, Johnson C, Faina M (2008). Community based vocational preparation for students with severe disabilities: designing the process. www.vcuedu/rrtcweb/techlink/iandr/voproj/chap1html.

[25] Jones K. \& Howley M. (2010). An investigation into an interaction programme for children on the autism spectrum: outcomes for children, perceptions of schools and a model for training. Journal of Research in Special Education Needs, Jun, 10(2): 115

[26] Op. cit. Inge K.J, Dymond S, Wehrnan P, Sutphin C, Johnson C, Faina M 2008. 